\title{
Heat Behavior of Electrically Conductive Concretes with and without Rebar Reinforcement
}

\author{
Heydar DEHGHANPOUR *, Kemalettin YILMAZ \\ Sakarya University, Engineering Faculty, Civil Engineering Department, 54187 Sakarya, Turkey \\ crossref http://dx.doi.org/10.5755/j01.ms.26.4.23053
}

Received 29 March 2019; accepted 15 July 2019

\begin{abstract}
Lately, electrically conductive concrete (ECC) is being investigated to prevent accumulation of snow and ice. The conductivity of electrical conductive concretes containing steel fiber is reduced by the corrosion of the steel fiber in time. Therefore, it is proposed to produce electrical conductive concretes that does not contain steel fibers recently. In this study, it is aimed to examine rebars in electrical conductive concretes non containing steel fiber. For this, $45 \times 45 \times 5 \mathrm{~cm}$ ECC slabs with and without $\Phi 10$ rebars were produced. Carbon fiber was used as a single fiber type in the mixtures. The heating times and thermal behaviors of the slab specimens were examined in a cooler at about $-10^{\circ} \mathrm{C}$. According to the results, the temperature in the rebars reinforced specimens has increased first in the regions near the electrodes and then proceeds towards the middle of the specimen. In non-rebars specimens, temperature rise has started from random points.

Keywords: electrical conductive concrete, prevent snow-icing, carbon fiber, nano carbon black.
\end{abstract}

\section{INTRODUCTION}

In recent years, the examination of different materials in electrically conductive concrete has become an interesting subject $[1-4]$. Electrically conductive concretes (ECCs) can be used in different areas [5-8]. ECC is a recommended type of concrete to prevent accumulation of snow and ice in the construction industry $[9,10]$. After snow and ice accumulation on the airport runways, the concrete threatening factor is the freeze-thaw event. In order to reduce the freeze-thaw effect that causes damage to the concrete, it is recommended to produce concretes with closed porosity or denser and non-porous structures. The aim of these classical methods is to produce more durable concrete against freeze-thaw by accepting the accumulation of snow and ice. Therefore, these methods are not a method to prevent damage to freeze-thaw cycles. Also, in snowy and cold weather, in streets, bridges and ramps, snow and ice accumulation leads to dangerous and deadly traffic [11].

From about 2000's, it has been recommended to apply ECCs, as a modern method for the solution of this problem. For the purpose of melting snow and ice, the production of electrically conductive concrete was first suggested by Yehia and Tuan [9].

Concrete is a material with low electrical conductivity. It is possible to reduce the electrical resistance of the concrete by the use of electrically conductive materials such as carbon, graphite, steel fibers and carbon fibers [2$4,8,12,13]$. In previous studies, fiber types were used to improve mechanical properties, generally. Amini was has studied strength of different fiber reinforced concrete in marine environment [14]. Different researchers examined the effect of fibers on post-cracking behaviour and fracture

\footnotetext{
* Corresponding author. Tel.: +90-538-2706088.

E-mail address: heydar.dehghanpour@ogr.sakarya.edu.tr (H. Dehghanpour)
}

energy [15], impact response and strength reliability [16] and development of concrete paving blocks prepared [17].

In 1999, Yehia and Tuan [9] produced ECC with steel fiber and shaving to prevent icing on bridge decks. The compressive strength of the produced conductive concrete was $40 \mathrm{MPa}$ and the electrical resistivity was measured between 500 and $1000 \Omega \cdot \mathrm{cm}$. According to the results of the heat test conducted in the laboratory, it was found that the power of $520 \mathrm{~W}$ was sufficient for the $10 \mathrm{~cm}$ thick $1 \mathrm{~m}^{2}$ conductive concrete to heat from -1.1 to $15.6{ }^{\circ} \mathrm{C}$. In his later work, Tuan and Yehiya [18] conducted a study supported by the Nebraska State Highway Authority. This scientific research consists of covering the surface of a bridge with electrically conductive concrete in Roca, south of Lincoln state of Nebraska. The area covered with conductive concrete has a width of $8.5 \mathrm{~m}$ and a length of $36 \mathrm{~m}$. An average of $590 \mathrm{~W} / \mathrm{m}^{2}$ thermal power was consumed to heat the conductive concrete coated to a speed of $0.14{ }^{\circ} \mathrm{C} / \mathrm{min}$. Galao et al. [5] produced and examined $30 \times 30 \times 2 \mathrm{~cm}$ carbon fiber reinforced conductive concrete slabs to prevent icing. According to the different mixes, the average thermal power was obtained as $71-526 \mathrm{~W} / \mathrm{m}^{2}$ for the specimens to be heated between 3 and $27^{\circ} \mathrm{C}$.

In 2016, ECC research at the airport in the state of Iowa is one of the most comprehensive and up-to-date studies [3,7, 19-23]. This project was carried out by Ceylan and his team and will continue until 2020. In the project, two $3.8 \times 4.6 \mathrm{ECC}$ slabs containing carbon fibers were produced [24]. The amount of power required to prevent snow accumulation was measured as $300-350 \mathrm{~W} / \mathrm{m}^{2}[7]$.

In the present study, it is aimed to examine the effect of rebars in ECC containing carbon fiber (CF) and nano carbon black (NCB). 


\section{EXPERIMENTAL}

\subsection{Materials}

Two different conductive filler materials were used in ECC mixtures. 6 wt.\% NCB as powder, and 0.5 vol. $\%$ and 1 vol.\% $\mathrm{CF}$ as fiber were used. The $\mathrm{CF}$ length, diameter and electrical resistivity were 6 and $12 \mathrm{~mm}, 7.2 \mu \mathrm{m}$ and $0.00155 \Omega \cdot \mathrm{cm}$, respectively. The NCB used is a type of carbon black obtained by pyrolysis from waste tires. Both the wires [25] and carbon [26] of waste tires can be evaluated in construction materials.

Both fine $(0-5 \mathrm{~mm})$ and coarse $(5-15 \mathrm{~mm})$ aggregates were used in equal proportions $850 \mathrm{~kg} / \mathrm{m}^{3}$. $450 \mathrm{~kg} / \mathrm{m}^{3}$ CEM 42.5 cement was used as binder. The water/binder ratio was maintained at 0.45 . In mixtures 0.2 wt.\% carboxy methyl cellulose (CMC) as fiber dispersant and 1.5 wt.\% superplasticizer (SP) were used. A schematic view of the mixing procedure is given in Fig. 1.

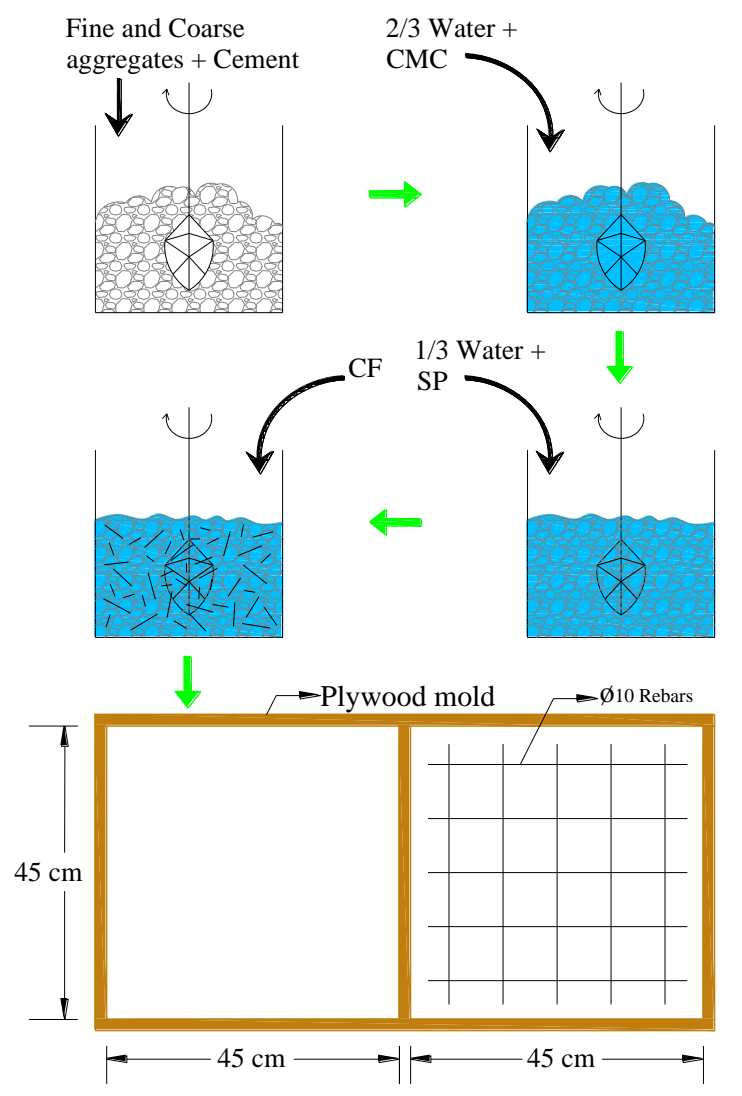

Fig. 1. Schematic view of the mixing procedure

\subsection{Method}

$10 \times 10 \times 40 \mathrm{~cm}$ Prismatic specimens and $10 \mathrm{~cm}$ diameter $20 \mathrm{~cm}$ high cylinder specimens were produced from each of the ECC mixtures produced. Prismatic specimens were used for the 3-point flexural test and the cylinder samples were first used for resistance measurement, then for pressure testing.

For the heat test, $5 \mathrm{~cm}$ thick $45 \times 45$ plate specimens were produced. The mold geometry of the slab specimens is shown in Fig. 1. From these specimens, a total of 4 units were produced, one with rebars and one without reinforcement (Table 1). For the plate specimens, two galvanized sheets of $1 \mathrm{~mm}$ thickness were used as electrodes (Fig. 2). To ensure good connection between the electrodes and the concrete, $5 \mathrm{~cm}$ length screws were connected at equal distances to the electrodes. For both mechanical and electrical-thermal tests, specimens were produced as shown in the Fig. 3. All samples were removed from the molds after 28 hours and kept in the curing pool for 7 days.

The mechanical tests of the specimens at the age of 28 days were performed using universal test equipment. The measurement of the resistances of the ECCs was carried out by two-point uniaxial method. This method is also used frequently in the literature [2-4,27]. In this method, a potential difference is applied between the two ends of the specimen and the amount of current realized is measured. The resistance of the specimen is obtained by putting the current value and applied voltage into ohm's law (Eq. 1). The resistivity is calculated from the Eq. 2.

$V=I \cdot R$

$p=R A / L$,

where $V$ is the applied voltage; $I$ is the measured current; $R$ is the resistance; $p$ is the resistivity; $L$ is the sample length; $A$ is the cross section of the specimen.

Heat test experiments were carried out in a cooler at about $-10^{\circ} \mathrm{C}$. By applying voltage between the two electrodes, the temperature change was monitored outside the cooler. $120 \mathrm{~V}$ has applied to slabs 1 and 2 and $80 \mathrm{~V}$ to slabs 3 and 4. Schematic view of the test apparatus is shown in Fig. 4. In order to monitor the temperature from outside, 9 thermometers were affixed at different points of the specimen surfaces (Fig. 5).

Table 1. Properties of ECC slabs

\begin{tabular}{|c|c|c|c|}
\hline Slab No & NCB, wt. $\%$ & CF, vol.\% & Rebars \\
\hline 1 & 6 & 0.5 & No \\
\hline 2 & 6 & 0.5 & Yes \\
\hline 3 & 6 & 1.0 & No \\
\hline 4 & 6 & 1.0 & Yes \\
\hline
\end{tabular}

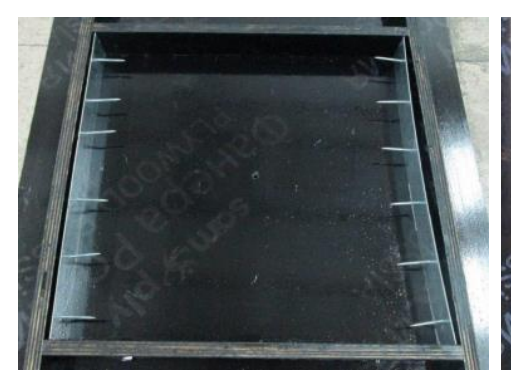

a

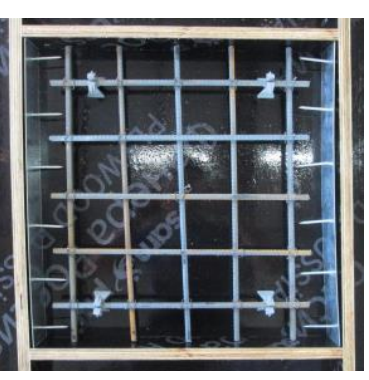

b
Fig. 2. Electrode attached molds: a-without rebars; b-with rebars

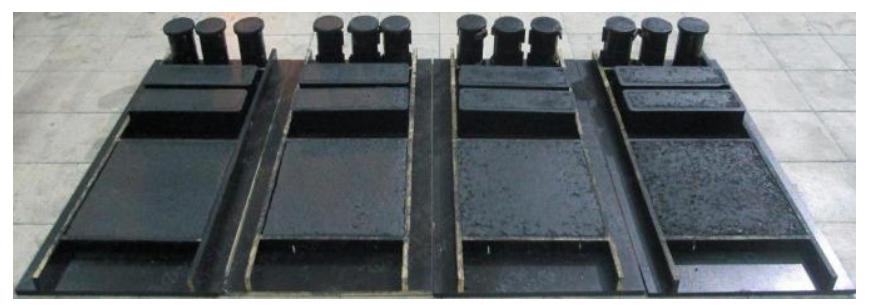

Fig. 3. Molding of specimens 


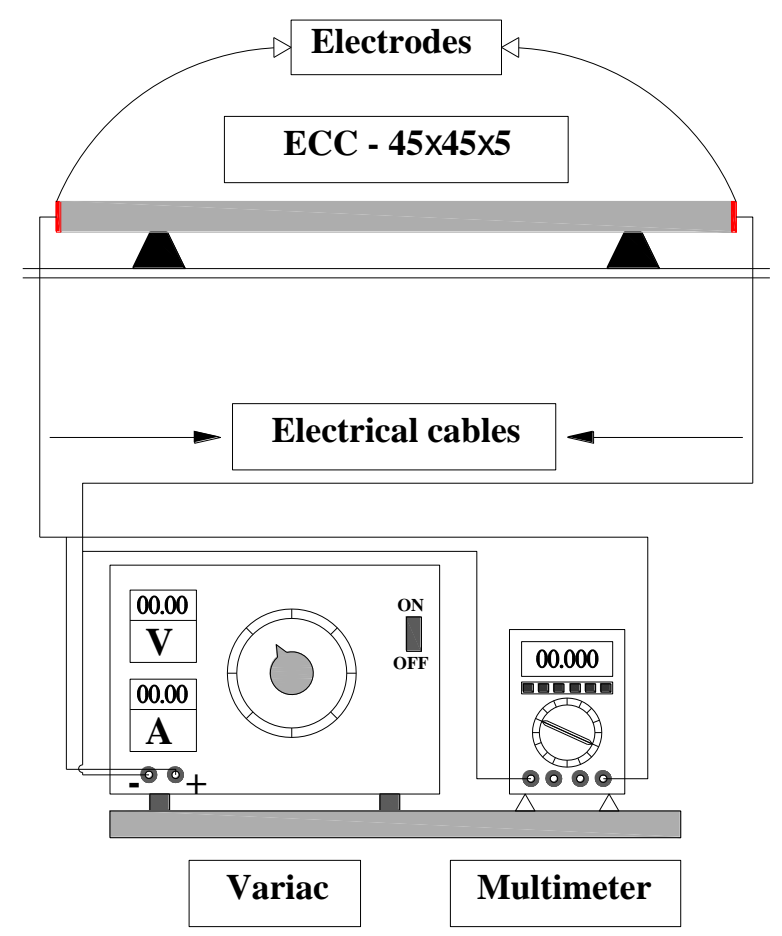

Fig. 4. Schematic view of the test apparatus

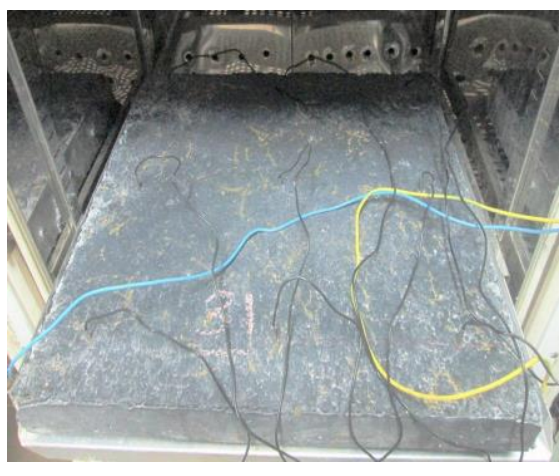

a

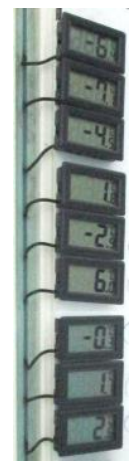

b
Fig. 5. $\mathrm{a}$-specimen in the cooler; $\mathrm{b}$-thermometer monitors outside the cooler

\section{RESULTS}

The electrical resistance and mechanical properties of ECCs obtained from two different mixtures are given in Table 2. The NCB ratio was fixed at $6 \mathrm{wt} . \%$ in both mixtures. In the $1^{\text {st }}$ mixture, $\mathrm{CF}$ was used at 0.5 vol. $\%$ and in the $2^{\text {nd }}$ mixture 1 vol. $\%$ was used. With an increase of $\mathrm{CF}$ from $0.5 \mathrm{vol} . \%$ to $1 \mathrm{vol} \%$, the electrical resistivity value decreased 2.78 times. However, the measured resistivity results are quite low and good. Sassani et al. [28] found the electrical resistivity of ECC containing $1 \mathrm{vol} . \% \mathrm{CF}$ as $800 \Omega \cdot \mathrm{cm}$. In addition, the use of CF in high dosages showed positive effects on the flexural and compressive strengths of ECCs containing $6 \mathrm{wt} . \%$ NCB.

Table 2. 28 Day, electrical and mechanical test results

\begin{tabular}{|c|c|c|c|c|}
\hline No & Mixture code & $\mathrm{BR}, \Omega \cdot \cdot \mathrm{cm}$ & $\sigma \mathrm{c}, \mathrm{MPa}$ & $\sigma \mathrm{f}, \mathrm{MPa}$ \\
\hline 1 & NCB6CF0.5 & 222.45 & 45.49 & 7.63 \\
\hline 2 & NCB6CF1.0 & 80.08 & 47.82 & 8.62 \\
\hline
\end{tabular}

In order to examine the heat performance of the slab specimens after the application of voltage, the temperatures of the slabs at an equal distance from 9 points were monitored and recorded. With the help of the measured temperature values, thermal cantor graphs of the slabs were drawn before and after heating (Fig. 6). At $t=0$, the few difference in temperature of $\mathrm{a}, \mathrm{c}$, e and $\mathrm{g}$ is due to the temperature difference in the cooler. In the nonreinforced slab containing $6 \% \mathrm{NCB}$ and $0.5 \% \mathrm{CF}$, the temperature distribution as shown in Fig. $6 \mathrm{~b}$ is not uniform. This can be commented by the inadequate $\mathrm{CF}$ dosage. The temperature of this slab after $120 \mathrm{~V}$ voltage application varies between 3.8 and 5.6 NCB. Although there is no significant difference in the temperature range of the reinforced sample with the same mixture, it is warming starting from both sides. The non-reinforced slab with $6 \% \mathrm{NCB}$ and $01 \% \mathrm{CF}$ is heated from two sides to middle as smetric. As shown in Fig. $6 \mathrm{f}$, the temperature range varies from 7 to $16{ }^{\circ} \mathrm{C}$. In addition, a defect in the temperature symmetry of the reinforced slab having the same mixture occurred (Fig. $6 \mathrm{~d}$ ).

In Fig. 7, the temperature changes of each of the 4 plates, depending on time, is given. A $120 \mathrm{~V}$ voltage was applied to both reinforced and non-reinforced slab specimens containing $6 \% \mathrm{NCB}$ and $0.5 \% \mathrm{CF}$. Both slab 1 and slab 2 specimens warmed with equal temperature values. The temperature increase rate for these samples was calculated as $2{ }^{\circ} \mathrm{C} / \mathrm{h}$.

In most studies it was stated that 300 to $550 \mathrm{~W} / \mathrm{m}^{2}$ of power is sufficient in conductive concretes to prevent accumulation of snow and ice [7, 9, 23, 29, 30]. In this study, a voltage of $80 \mathrm{~V}$ was applied to the slab 3 and slab 4 samples which were over conductive to protect this limitation. The non-reinforced slab 3 , with $6 \% \mathrm{NCB}$ and $1 \% \mathrm{CF}$, warmed at high speed from $-10 \mathrm{C}$ to $12.6 \mathrm{C}$ in 1 hour. The reinforced slab 4 in the same mixture warmed from $-10{ }^{\circ} \mathrm{C}$ to $8.5^{\circ} \mathrm{C}$ in 2.5 hours. Therefore, the use of rebars in excessively conductive concretes is a major disadvantage in terms of conductivity. The reason for this can be explained by the fact that most of the electric current passes through the rebars rapidly and prevents the concrete from heating.

However, the rebars did not have a positive or negative effect on the low conductor slab. Also, nonreinforced slab with $6 \% \mathrm{NCB}$ and $1 \% \mathrm{CF}$ was heated in the shortest period of time and at the highest level compared to other specimens. In Fig. 6, temperature-time formulas for slabs 1-4 are formed and given in equations $3-6$ below. The regression coefficients $\left(R^{2}\right)$ for all equations are close to 1 .

$$
\begin{array}{ll}
R^{2}=0.9942 & y=0.0401 x-9.8487 ; \\
R^{2}=0.9968 & y=0.0354 x-9.4329 ; \\
R^{2}=0.9459 & y=0.4101 x-12.598 ; \\
R^{2}=0.9826 & y=0.1193 x-8.7823,
\end{array}
$$

where $y$ is the temperature change; $x$ is the time. The current $I$ after the voltage applied to the slab specimens was measured, the amount of power $P$ spent was calculated 
and summarized in Table 3. For reinforced and nonreinforced specimens containing $6 \% \mathrm{NCB}$ and $0.5 \% \mathrm{CF}$, $120 \mathrm{~V}$ were applied due to their low conductivity. The average of $0.28 \mathrm{~A}$ was measured for the non-reinforced slab and $0.30 \mathrm{~A}$ for reinforced slab. The amount of power spent was calculated, from equation 7 , to be 165.9 for nonreinforced and 177.8 for reinforced.

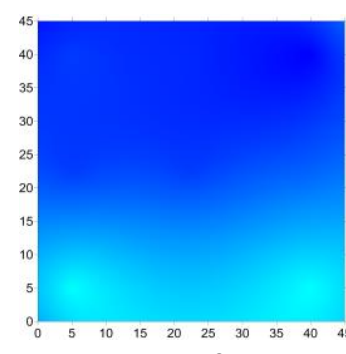

a
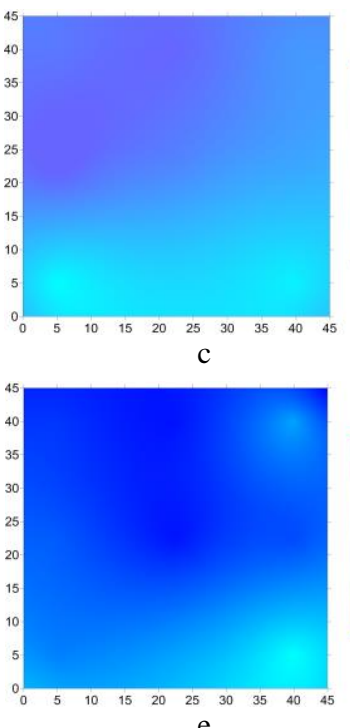

g

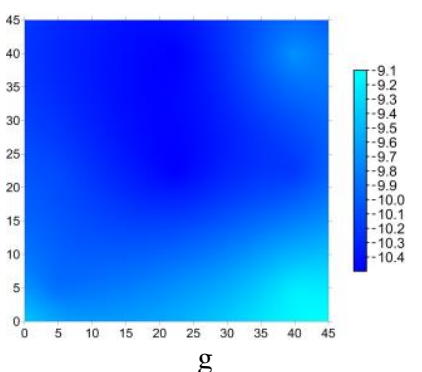

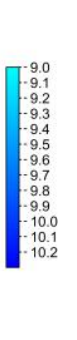
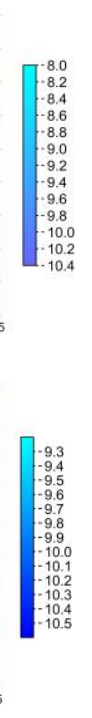
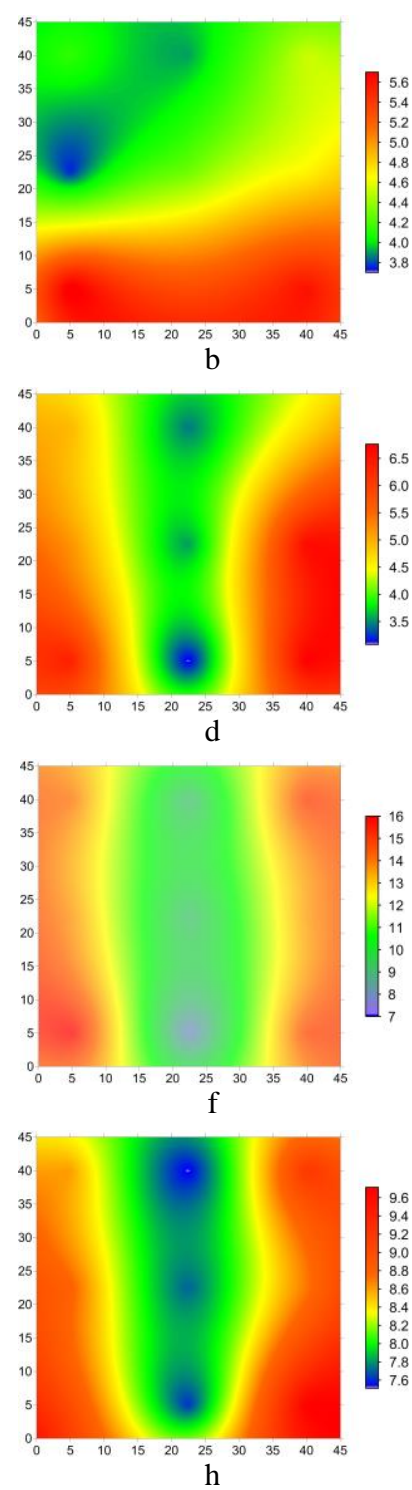

Fig. 6. a, c, e, g-thermal cantor views of slabs at $t=0 ; \mathrm{b}, \mathrm{d}, \mathrm{f}$, $\mathrm{h}-\mathrm{t}=$ end of the experiment

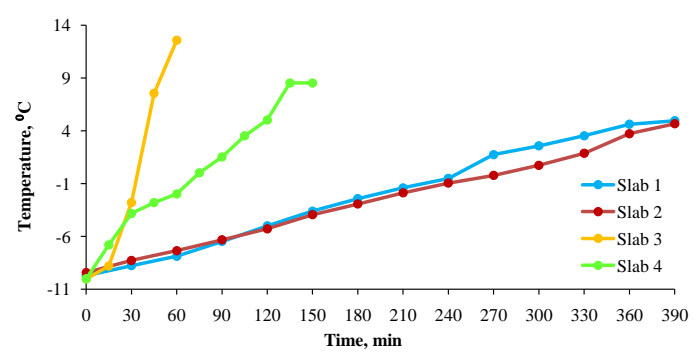

Fig. 7. Temperature change of slabs depending on time
Therefore, the rebars has no significant effect on the concrete slab with this mixture. However, in slabs 3 and 4 with $1 \% \mathrm{CF}$, the amount of power spent in the reinforced state has increased almost threefold. However, in slabs 3 and 4 with $1 \% \mathrm{CF}$, the amount of energy consumed in the reinforced state has increased almost threefold, although there is no significant difference in the amount of power spent. The amount of energy increased with increasing time. The amount of energy was obtained by multiplying the amount of power with time.

$P=V \cdot I$.

Table 3. Heat performances of slabs specimens

\begin{tabular}{|c|c|c|c|c|c|c|}
\hline $\begin{array}{c}\text { Slab } \\
\text { No }\end{array}$ & $\begin{array}{c}\text { Voltage, } \\
\mathrm{V}\end{array}$ & $I, \mathrm{~A}$ & $\begin{array}{c}\Delta T, \\
{ }^{\circ} \mathrm{C}\end{array}$ & $\begin{array}{c}P, \\
\mathrm{~W} / \mathrm{m}^{2}\end{array}$ & $\Delta t, \mathrm{~h}$ & $\begin{array}{c}\text { Energy, } \\
\mathrm{kW} \cdot \mathrm{h} / \mathrm{m}^{2}\end{array}$ \\
\hline 1 & 120 & 0.28 & 14.1 & 165.9 & 6.5 & 1.08 \\
\hline 2 & 120 & 0.30 & 14.7 & 177.8 & 6.5 & 1.16 \\
\hline 3 & 80 & 1.05 & 22.6 & 418.8 & 1.0 & 0.418 \\
\hline 4 & 80 & 1.15 & 18.8 & 454.32 & 2.5 & 1.14 \\
\hline
\end{tabular}

The amounts of power consumed for the four specimens are compared in Fig. 8. Because the power consumed for slabs 1 and 2 is low, the slabs require a long time to heat up. Also, according to the literature, the power values suitable for ECCs are specified as $300-550 \mathrm{~W} / \mathrm{m}^{2}$. Therefore, slab 3 is suitable for this study in terms of power. Temperature of slab 2 increased from $-10^{\circ} \mathrm{C}$ to $+10{ }^{\circ} \mathrm{C}$ at $60 \mathrm{~min}$ with a power of $418.8 \mathrm{~W} / \mathrm{m}^{2}$.

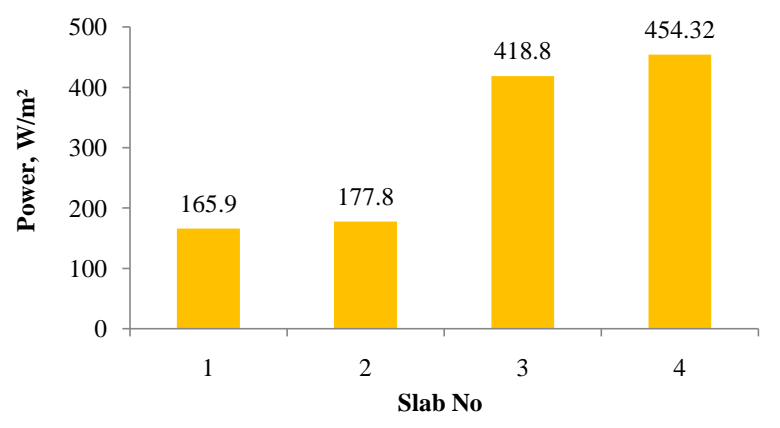

Fig. 8. Comparison of consumed power values

\section{CONCLUSIONS}

In this study, the effect of the rebars on the conductive concrete slab was investigated. The warming interval, warm-up time and the amount of power spent for ECC plates were calculated. The results are listed below:

The electrical resistances of the slab specimens were measured at a significant high level relative to the resistances of the cylinder specimens. This change adversely affects the formation of heat.

Along with the lack of any effect on the low conductive sheet of the rebars, the adverse effect on the excess conductive concrete plate was understood.

The negative effect of rebars on the excess conductive concrete slab can be explained by the rapid flow of electricity from the rebars and slowing of heat generation. As a result, the use of rebars in ECC is not proposed because of the negative effect of rebar. 
According to the results of this study, the most ideal system for heated floors is recommended non-reinforced slab with 6 wt.\% NCB and 1 vol.\% CF.

In subsequent studies, it is recommended to examine the effect of polypropylene fibers to prevent cracking in electrically conductive concretes.

\section{Acknowledgments}

Authors wish to thank Sakarya University, Engineering faculty for technical assistance.

\section{REFERENCES}

1. Tuan, C.Y. Electrical Resistance Heating of Conductive Concrete Containing Steel Fibers and Shavings Materials Journal 101 (1) 2004: pp. 65-71.

2. Wu, J., Liu, J., Yang, F. Three-Phase Composite Conductive Concrete for Pavement Deicing Construction and Building Materials 75 2015: pp. 129-135. https://doi.org/10.1016/j.conbuildmat.2014.11.004

3. Sassani, A., Ceylan, H., Kim, S., Gopalakrishnan, K., Arabzadeh, A., Taylor, P. Factorial Study on Electrically Conductive Concrete Mix Design for Heated Pavement Systems Proccedings Transportation Research Board 96th Annual Meeting, Washington DC. 2017: pp. 17-05347.

4. El-Dieb, A.S., El-Ghareeb, M.A., Abdel-Rahman, M.A., EI Sayed, A.N. Multifunctional Electrically Conductive Concrete Using Different Fillers Journal of Building Engineering 15 2018: pp. 61-69. https://doi.org/10.1016/j.jobe.2017.10.012

5. Galao, O., Bañón, L., Baeza, FJ., Carmona, J., Garcés, P. Highly Conductive Carbon Fiber Reinforced Concrete for Icing Prevention and Curing Materials 9(4) 2016: pp. $281-295$. https://doi.org/10.3390/ma9040281

6. Galao, O., Baeza, F.J., Zornoza, E., Garcés, P. Strain and Damage Sensing Properties on Multifunctional Cement Composites with Cnf Admixture Cement and Concrete composites 46 2014: pp. 90-98. https://doi.org/10.1016/j.cemconcomp.2013.11.009

7. Sassani, A., Ceylan, H., Kim, S., Arabzadeh, A., Taylor, P.C., Gopalakrishnan, K. Development of Carbon Fiber-Modified Electrically Conductive Concrete for Implementation In Des Moines International Airport Case Studies in Construction Materials 8 2018: pp. 277-291. https://doi.org/10.1016/j.cscm.2018.02.003

8. Khalid, T., Albasha, L., Qaddoumi, N., Yehia, S. Feasibility Study of Using Electrically Conductive Concrete for Electromagnetic Shielding Applications as a Substitute for Carbon-Laced Polyurethane Absorbers in Anechoic Chambers IEEE Transactions on Antennas and Propagation 65 (5) 2017: pp. 2428-2435. https://doi.org/10.1109/TAP.2017.2670538

9. Yehia, S., Tuan, C.Y. Conductive Concrete Overlay for Bridge Deck Deicing Materials Journal 96 (3) 1999: pp. 382-390.

10. Yehia, S., Tuan, C.Y., Ferdon, D., Chen, B. Conductive Concrete Overlay for Bridge Deck Deicing: Mixture Proportioning, Optimization, and Properties Materials Journal 97 (2) 2000: pp. $172-181$.

11. Zhao, H.M., Wang, S.G., Wu, Z.M., Che, G.J. Concrete Slab Installed with Carbon Fiber Heating Wire for Bridge Deck Deicing Journal of Transportation Engineering 136 (6) 2009: pp. 500-509.
https://doi.org/10.1061/(ASCE)TE.1943-5436.0000117

12. Arabzadeh, A., Ceylan, H., Kim, S., Gopalakrishnan, K., Sassani, A., Sundararajan, S., Taylor, P.C., Abdullah, A. Influence of Deicing Salts on The Water-Repellency of Portland Cement Concrete Coated with Polytetrafluoroethylene and Polyetheretherketone Airfield and Highway Pavements 2017: pp. 217-227. https://doi.org/10.1061/9780784480946.020

13. Dehghanpour, H., Yilmaz, K., Ipek, M. Evaluation of Recycled Nano Carbon Black And Waste Erosion Wires in Electrically Conductive Concretes Construction and Building Materials 221 2019: pp. 109-121. https://doi.org/10.1016/j.conbuildmat.2019.06.025

14. Aini, F., Bafghi, M.A.B. Safayenikoo, H., Sarkardeh, H. Strength of Different Fiber Reinforced Concrete in Marine Environment Materials Science (Medžiagotyra) $24(2)$

2018: pp. $204-211$. https://doi.org/10.5755/j01.ms.24.2.17909

15. Kosior-Kazberuk, M. Post-Cracking Behaviour and Fracture Energy of Synthetic Fibre Reinforced Concrete Materials Science (Medžiagotyra) 22 (4) 2016: pp. $542-$ 547. https://doi.org/10.5755/j01.ms.22.4.13246

16. Gunasekaran, M., Thangavel, M., Nemichandran, N.K., Ravikumar, I., Glarance, H.J., Kothandapani, K. Impact Response and Strength Reliability of Green High Performance Fibre Reinforced Concrete Subjected to Freeze-Thaw Cycles in Nacl Solution Materials Science (Medžiagotyra) 23 (4) 2017: pp. 384-388. https://doi.org/10.5755/j01.ms.23.4.17334

17. Namarak, C., Bumrungsri, C., Tangchirapat, W., Jaturapitakkul, C. Development of Concrete Paving Blocks Prepared from Waste Materials Without Portland Cement Materials Science (Medžiagotyra) 24 (1) 2018: pp. 92 -99. https://doi.org/10.5755/j01.ms.24.1.17566

18. Tuan, C.Y., Yehia, S. Evaluation of Electrically Conductive Concrete Containing Carbon Products for Deicing Materials Journal 101 (4) 2004: pp. 287-293.

19. Gopalakrishnan, K., Ceylan, H., Kim, S., Yang, S., Abdualla, H. Self-Heating Electrically Conductive Concrete for Pavement Deicing: A Revisit Transportation Research Board 94th Annual Meeting 2015: pp. 15-4764.

20. Gopalakrishnan, K., Ceylan, H., Kim, S., Yang, S., Abdualla, H. Electrically Conductive Mortar Characterization for Self-Heating Airfield Concrete Pavement Mix Design International Journal of Pavement Research and Technology 8 (5) 2015: pp. 315-324. https://doi.org/10.6135/ijprt.org.tw/2015.8(5).315

21. Abdulla, H., Ceylan, H., Kim, S., Gopalakrishnan, K., Taylor, P., Turkan, Y. System Requirements for Electrically Conductive Concrete Heated Pavements Transportation Research Record Journal of the Transportation Research Board 2569 2016: pp. 70-79. https://doi.org/10.3141/2569-08

22. Abdualla, H., Ceylan, H., Kim, S., Mina, M., Gopalakrishnan, K., $\quad$ Sassani, A., $\quad$ Taylor, P.C., Cetin, K.S. Configuration of Electrodes for Electrically Conductive Concrete Heated Pavement Systems Airfield and Highway Pavements 2017: pp. 1-9. https://doi.org/10.1061/9780784480946.001

23. Sassani, A., Arabzadeh, A., Ceylan, H., Kim, S., Sadati, S.S., Gopalakrishnan, K., Taylor, P.C., Abdualla, H. Carbon Fiber-Based Electrically Conductive Concrete for Salt-Free Deicing of Pavements Journal of 
Cleaner Production 203 2018: pp. 799-809. https://doi.org/10.1016/j.jclepro.2018.08.315

24. Sadati, S.S., Cetin, K., Ceylan, H. Numerical Modeling of Electrically Conductive Pavement Systems ASCE Congress on Technical Advancement 2017. pp. 111-120. https://doi.org/10.1061/9780784481011

25. Dehghanpour, H., Yılmaz, K. Mechanical and Impact Behavior on Recycled Steel Fiber Reinforced Cementitious Mortars Russian Journal of Building Construction and Architecture 39 (3) 2018: pp. 67-84.

26. Dehghanpour, H., Yılmaz, K. Microstructure Characterization of Nano Carbon Black Obtained by Combustion Method for Use in Concrete 1st International Symposium on Light Alloys and Composite Materials (ISLAC'18) 2018: pp. 511-512.

27. Ghosh, P., Tran, Q. Correlation Between Bulk and Surface Resistivity of Concrete International Journal of Concrete Structures and Materials 9 (1) 2015: pp. 119-132. https://doi.org/10.1007/s4006
28. Sassani, A., Ceylan, H., Kim, S., Gopalakrishnan, K., Arabzadeh, A., Taylor, P.C. Influence of Mix Design Variables on Engineering Properties of Carbon FiberModified Electrically Conductive Concrete Construction and Building Materials 152 2017: pp. 168-181. https://doi.org/10.1016/j.conbuildmat.2017.06.172

29. Tuan, C.Y. Roca Spur Bridge: the Implementation of an Innovative Deicing Technology Journal of Cold Regions Engineering 22 2008: pp. 1-15. https://doi.org/10.1061/(ASCE)0887-381X(2008)22:1(1)

30. Abdualla, H., Ceylan, H., Kim, S., Mina, M., Cetin, K.S., Taylor, P.C., Vidyadharan, A. Design and Construction of the World's First Full-Scale Electrically Conductive Concrete Heated Airport Pavement System at a US Airport Transportation Research Record 2672 (23) 2018: pp. $82-94$. https://doi.org/10.1177/0361198118791624

(C) Dehghanpour et al. 2020 Open Access This article is distributed under the terms of the Creative Commons Attribution 4.0 International License (http://creativecommons.org/licenses/by/4.0/), which permits unrestricted use, distribution, and reproduction in any medium, provided you give appropriate credit to the original author(s) and the source, provide a link to the Creative Commons license, and indicate if changes were made. 